\title{
The Changing Residential Patterns of Immigrants - The Case of Sweden 1973-1992
}

\section{LARS-ERIK BORGEGÅD}

Associate Professor

\section{JOHAN HÅKANSSON}

Doctoral Student

\section{DIETER K. MÜLLER}

\author{
Doctoral Student \\ Department of Social and Economic Geography \\ Umeå University \\ Umeå, Sweden
}

\begin{abstract}
Swedish immigration policy has recently changed. The plan known as "Whole of Sweden Strategy" no longer applies, and there is greater freedom to choose where one lives. Migration is important in the redistribution of the population, and thus immigration plays a significant role. In light of this, there are good grounds for following how concentration and dispersion of immigrant groups vary, both geographically and in time.
\end{abstract}

Keywords: immigration policy, migration, Sweden

\section{Introduction}

Due to their rising number, immigrants have become more important as regards changes in the geographical distribution of the population in the receiver countries (Champion 1994). From a geographical perspective it is therefore very important to know about the geographical redistribution of immigrants once they are settled in their new countries.

The literature treating international migration can be divided into two relatively separate categories (Champion 1994). One focuses on international migration per se, while the other primarily deals with minority and integration problems in various countries. However, there has been rather little investigation in the international literature of the link between these two areas: for instance, the outcome of international migration in different countries regarding geographical and demographical redistribution of the immigrant population and its effects on the distribution of the whole population. The beginning of the 1970s saw a break in the urbanization trends in Sweden, as well as the western world, in general. More people moved away from cities than moved 
into them. In Sweden this process has been called the "green wave". During the 1980s, however, migration again reversed, and one of the main explanations for this is demographic changes in which immigrants play a major role. Thus Sweden is one case where international migration has acquired more significance in the geographical distribution of the population.

In this article we address three components of immigration:

- immigration to Sweden,

- the special distribution of immigrants in the country,

- the redistribution of the various immigrant groups.

Our aim is to analyze the distribution of different immigrant groups in the country in terms of concentration and dispersion. Our hypothesis is that the reason for immigration, the policy prevailing in Sweden, the time spent in the country of immigration and the size of the immigrant group all influence geographical redistribution of immigrants. The study is operationalized by a classification of the different immigrant groups. It distinguishes some of the above-mentioned factors which differ between different immigrant groups. The hypothesis has been broken down into the following questions: Are there differences between labor immigrants (guest workers) and refugees in their residential patterns? How does the residential pattern change in terms of concentration and dispersion when the immigrant group grows larger? Has the immigration and refugee policy of the late 1980 s affected the residential patterns of immigrants in terms of concentration and dispersion on the municipal and regional levels? To measure this we have used the Hoover Index (Hoover 1941), an established device within traditional population geography (Isard 1960; Duncan et al. 1961; Vining and Strauss 1977). As with several segregation measures, this index basically measures dissimilarities. The difference between commonly used measures of concentration based on a proportion of the population - for example, several measures of segregation - is that the Hoover Index is spatially proportional, that is, it measures the differences between the relative distribution of the population and the relative distribution of geographic area between, for example, municipalities. One advantage of the Index is its dependence on the geographic level on which the measure of the population is made. By using the Index on different geographical levels, we not only obtain a picture of the extent to which the population is concentrated and dispersed, but also whether the geographic redistribution on one geographic level agrees with the geographic redistribution on another. The geographical units that will be used in this study are Swedish municipalities and provinces

\section{International migration and its impact on immigration to Sweden}

At present, media attention and scientific discussion are highly focused on international migration (Castles and Miller 1993; Collinson 1993; Fassmann and Münz 1994; King 1993; Salt 1992, 1993). Nevertheless, two areas in international migration research have largely landed outside both the public and scientific discussion. The first area concerns the link between international migration and minority problems, i.e. the effects of migration on population distribution, structure and development - areas that are little researched. In Sweden, migration during the 1980 s has meant a great deal for the recent positive population development in many municipalities (Andersson 1993). The second area has to do with moving between socioeconomically similar states (the migration of highly educated people), which has long been overshadowed by more dramatic immigration (Gould 1988). In Sweden during recent years, about one-fourth of all immigrants belonged to this group.

One way to describe the development of the total immigration has been presented 
by White (1993), who argues that there have been three waves of immigration to the northwestern European industrial nations after the Second World War. The first, during the 1950 s and 1960 s, was composed of an immigration of labor, partly as a result of active recruitment in southern Europe. The second wave, which peaked during the 1970 s, was dominated by family-related immigration - usually women and children related to the already arrived labor force from southern Europe. Up to the middle of the 1970 s, immigrants mainly came from southern European countries. However, the situation changed after the last half of the $1970 \mathrm{~s}$, and the third wave of immigrants to industrialized countries was dominated by refugees from many scattered regions of the world. This third phase is also marked by a sometimes explosive increase of refugee migration.

This global development model generally reflects the various phases of immigration to Sweden. However, an important part of the latter lands somewhat outside of this three-wave pattern because of the common Nordic labor market, a large part of the labor force needed in Sweden was recruited from Finland (Häggström et al. 1990). Already in the 1950 s and 1960 s the political situation in eastern Europe caused large groups of refugees to flee to Sweden. There is also a constant immigration from other immigration states like Germany and Great Britain; German immigration especially, comprises an important element in postwar immigration to Sweden (Müller1994).

In Sweden, the relations between surplus immigration and natural increase in later years can be illustrated with the so-called demographic clock (Figure 1). Non-Swedish citizens have comprised about $80 \%$ of the population increase in Sweden between 1973 and 1992. Foreign citizens have also recently had a relatively sizable influence on the redistribution of the population. On the local level, immigration has been extremely important for the positive population development in many municipalities during the 1980s, including peripheral municipalities (Andersson 1993). On the national level, however, immigration has led to concentration in the geographical redistribu-

$\mathrm{Fig} \mathrm{u} \mathrm{re} \mathrm{1.} \mathrm{The} \mathrm{relation} \mathrm{between} \mathrm{net} \mathrm{immigration} \mathrm{and} \mathrm{net} \mathrm{natural} \mathrm{population} \mathrm{increase}$ in Sweden 1974-1992. (The diagonal line shows where the influence between immigration and natural increase is equal. Above the diagonal line immigration has the bigger impact on population growth, below, the impact of natural increase is bigger.)

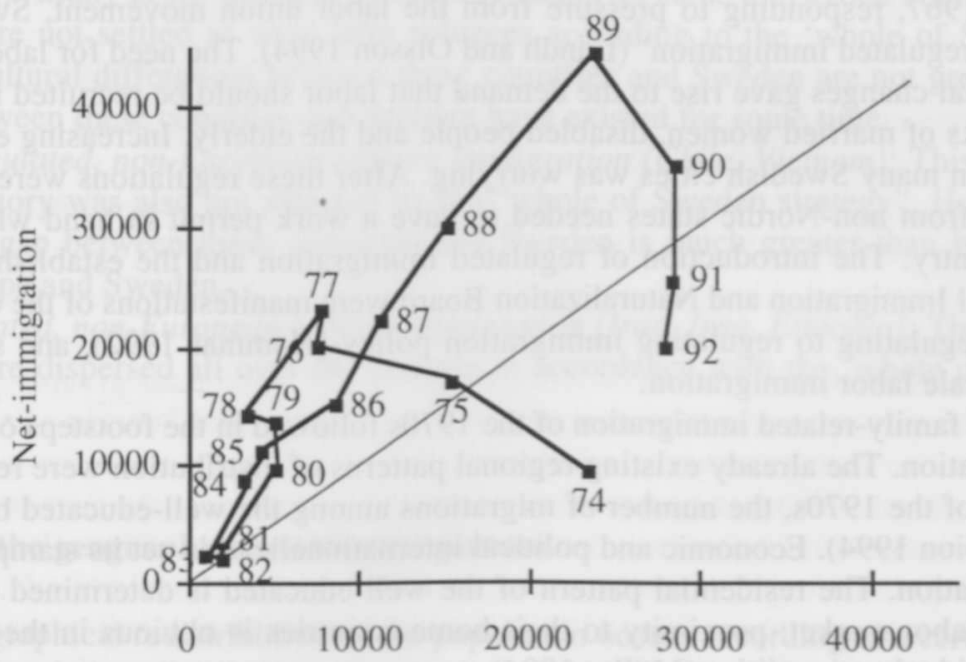

Natural increase 
tion of the population. In big city areas today, in terms of net in-migration, most of the external contributions towards an increase in population consist of immigrants (Borgegård and Håkansson 1995).

Although on different geographical levels, concentration and dispersion occur simultaneously in the long-term population redistribution in Sweden. Concentration on the local level has been expressed, for example, in increased segregation in the cities during the 1980s. The pattern of the various levels can change over time, however; the same may probably be said of the immigrants as well. What the residential patterns of the various immigrant groups - as well as of the native populations - will become, is affected by structural social conditions and their variations throughout the country. These conditions provide different opportunities for different groups of immigrants. Along with this, variations in the pattern among immigrants over time can be linked to information, which varies depending on the multivarious reasons behind their immigration. Another important factor is prevailing government policy, which not only largely determines who is allowed into the country but also how geographical mobility may be affected. Finally, the size of the immigrant groups and how long they have been in Sweden may be seen as indicators of how contact networks - the number of links and contact possibilities - between the immigrants themselves and between immigrants and Swedes change and multiply.

\section{Immigration and immigrant policy in Sweden}

In the year 1954 Sweden introduced a modern immigration policy. Sweden signed the Geneva Conventions on refugees, and with its Nordic neighbors, entered into a common labor market which allowed unhindered movement within Scandinavia (Lundh and Olsson 1994).

As a consequence of Sweden's enormous industrial success many Finnish citizens flocked to its industrial regions (Häggström et al. 1990). This was welcomed as labor was in short supply in the industrial communities in central Sweden. Subsequent recruitment of labor from southern Europe, especially Yugoslavia and Greece, but also Italy and Turkey, occurred in a very liberal atmosphere. The distribution of the population, including that of immigrants, was then not steered by political instruments but regulated by labor market forces.

In 1967, responding to pressure from the labor union movement, Sweden introduced 'regulated immigration' (Lundh and Olsson 1994). The need for labor remained, but social changes gave rise to the demand that labor should be recruited mainly from the ranks of married women, disabled people and the elderly. Increasing ethnic segregation in many Swedish cities was worrying. After these regulations were introduced, people from non-Nordic states needed to have a work permit in hand when entering the country. The introduction of regulated immigration and the establishment of the National Immigration and Naturalization Board were manifestations of the change from a non-regulating to regulating immigration policy (Hammar 1992), and set a stop to large-scale labor immigration.

The family-related immigration of the 1970 s followed in the footsteps of labor force immigration. The already existing regional patterns of distribution were reinforced.

As of the 1970 s, the number of migrations among the well-educated began to rise (Champion 1994). Economic and political internationalization set its stamp on patterns of migration. The residential pattern of the well-educated is determined only in part by the labor market: proximity to their home countries is obvious in the distribution of individual nationalities (Müller 1994).

From 1984 to 1994 , the 'whole of Sweden strategy' determined the distribution of 
the 1980 s refugee immigrants over the entire country. The advantage with this policy was that the financial and social burden for individual municipalities was mitigated. On one hand, the 'whole of Sweden strategy' entailed a possibility for several sparsely populated municipalities to attain a more balanced population structure. On the other, after being placed in a sparsely populated area for a year, many immigrants moved to larger centers, to workplaces and to be near relatives. The effects of the 'whole of Sweden strategy' on more long-term population distribution are therefore unclear.

\section{Classes of immigrant groups}

Immigrants comprise a heterogeneous group. Varying prerequisites lead to different spatial behavior, for instance, as regards regional migrations. However, there are common denominators between nationalities concerning reasons for immigrating and the policy they have encountered, which means that some factors are the same for some immigrant groups while other factors distinguish immigrant groups from each other. Nationalities can be classified into a number of main groups especially regarding reasons for immigrating and policy questions. The classification thereby also expresses differences among the immigrant groups in time spent in Sweden.

1. Unregulated neighboring country immigration (Norway, Finland, Denmark, Iceland): According to the agreement on a common Nordic labor market, Nordic citizens have almost unlimited freedom of movement between the Nordic countries.

2. Labor force and family-related immigration from emigration countries (Yugoslavia, Italy, Spain, Portugal, Greece, Turkey): The causes of this immigration were mainly the need for a work force in Swedish industry during the 1950s and 1960s. For these immigrants, the move nearly always meant a step towards a better standard of living. The family-related immigration of the 1970 s also belongs to this category, and was steered by distribution patterns already existing in Sweden.

3. Labor immigration from immigration countries (Germany, France, Great Britain, Belgium, Holland, the US, Canada): These states underwent a similar development to that of Sweden. The reasons behind emigration from these countries are therefore more of an individual than structural nature.

4. European refugee immigration (Poland, Hungary, Czechoslovakia, Rumania, the Soviet Union): Many of the refugees from these countries came to Sweden before 1970 and thus were not settled as were later refugees according to the 'whole of Sweden strategy'. Cultural differences between these countries and Sweden are not great, and contacts between these countries and Sweden have existed for some time.

5. Unregulated, non-European refugee immigration (Chile, Vietnam): This immigration category was also not affected by the "whole of Sweden strategy". However, the cultural gap between these countries and Sweden is much greater than between eastern Europe and Sweden.

6. Regulated, non-European refugee immigration (Iran, Iraq, Ethiopia): These immigrants were dispersed all over the country in accordance with the 'whole of Sweden strategy'.

\section{Changes in the geographical residential pattern}

The geographical redistribution of the population occurs according to a certain geographical population distribution at a particular time. In Sweden, the geographical distribution of the population is and has always been fairly concentrated. The degree 
of concentration on the regional level, measured according to the Hoover Index, is as high today as it was in the beginning of the 19th century (Borgegård et al. 1995). Heavy urbanization during the 19th century led to greater local concentration in the cities. At present, about $50 \%$ of the country's population live in the three big city areas and in university municipalities, which together comprise less than $10 \%$ of the country's area. Immigrants are even more concentrated, with about $66 \%$ of the population living in these metropolitan areas.

The selected immigrant groups illustrate waves of immigration over time (Figure 2). At the beginning of the period, the European immigrant groups - except for Turks had already attained a size which was basically maintained - or decreased somewhat. The wave of family-related immigration which followed upon the initial immigration has ebbed out and many of the European immigrants have been in Sweden a long time. Accordingly, increased return to their home countries and acquiring Swedish citizenship may explain the reductions in the immigrant populations. However, this pattern does not apply to the Turks. Along with Yugoslavs, Turks were recruited to and established residences in Swedish industrial regions during the 1960s. Nevertheless, the greater part of the rise in population occurred during the 1970 s - albeit after a residential pattern had been established in the 1960s. Population expansion in the other groups (non-European immigrants) occurred from 1970 onwards. Increases among the different populations took place at different times: among Chileans and Iranians mainly during the $1980 \mathrm{~s}$ - though as regards the Chileans, mostly before the introduction of the 'whole of Sweden strategy' in 1984, while the opposite was true for the Iranians.

Fig u re 2. Population increases among different immigrant groups in 1973-92. (Changes in the Finnish population are indicated on the right axis, while those in the other nationalities are found on the left axis.)

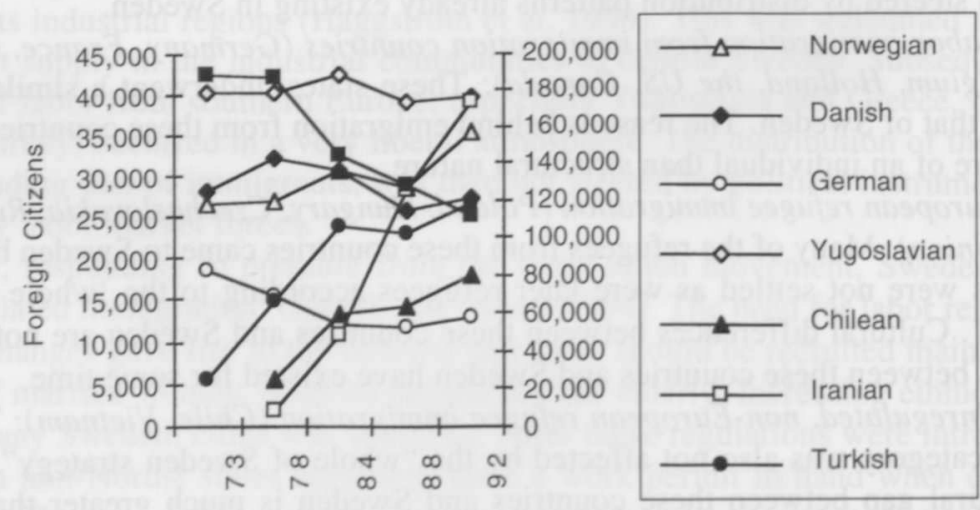

This means that there are differences among the immigrant groups studied as regards the structural conditions under which immigration to Sweden occurred. Politi$\mathrm{cal}$ influence varies amongst the groups. Some of the groups studied established residential patterns before the beginning of the period and before the introduction of regulated immigration. A few have been established during the 1970 s, after the introduction of regulated immigration but before the "whole of Sweden' policy". A couple of the immigrant groups established residental patterns after this policy was introduced, which means that there are differences in length of stay among the various groups studied. 


\section{Variations in degree of concentration 1974-1992}

Regardless of time period and immigrant status (labor immigration, family-related, refugee), immigrants are more concentrated than the Swedish population (Table 1 below). The questions remain whether they become more dispersed when the groups increase (that is, when more contacts are made), what differentiates immigrant groups in this respect and what are the effects of immigration policy on the residential patterns immigrant groups'.

$\mathrm{T}$ a b l e 1. Hoover Index of municipalities.

$\begin{array}{lllllllllll} & \text { Swedish Finnish } & \text { Norw. } & \text { Danish } & \text { German } & \text { Yugosl. } & \text { Chilean } & \text { Iranian } & \text { Turkish } \\ 1973 & 55.81 & 72.81 & 66.96 & 73.30 & 70.71 & 80.26 & . & . & 90.16 \\ 1978 & 55.93 & 73.16 & 65.72 & 71.78 & 70.16 & 81.02 & 88.29 & 86.34 & 88.94 \\ 1984 & 56.23 & 73.67 & 68.29 & 73.38 & 70.35 & 82.05 & 92.67 & 91.99 & 90.27 \\ 1988 & 56.71 & 73.71 & 66.38 & 70.91 & 70.53 & 81.58 & 83.47 & 71.68 & 88.45 \\ 1992 & 57.70 & 73.33 & 64.46 & 70.28 & 70.57 & 79.21 & 80.13 & 75.90 & 84.43\end{array}$

The degree of concentration varies among the different ethnic immigrant groups (Table 1). These variations seem to depend on the size of the groups, among other things (Håkansson 1992). Immigrants are not only more concentrated than the Swedish population, they are also concentrated in different geographical areas (ibid.). Germans have no distinguished concentration in southern Sweden. However, Finns, Turks, and Chileans mostly live in the provinces around Lake Mälaren. Turks and Chileans are more concentrated in the province of Stockholm than Finns are. The majority of Danes, Norwegians, and Yugoslavs are more concentrated in the southern and western provinces of Sweden. The proportion of Danes, Norwegians and Yugoslavs living in the province of Stockholm does not differ much from this province's proportion of the total population. The regional patterns also indicate differences in the types of localities in which different groups are concentrated. Labor immigrants are mainly concentrated in large urban municipalities.

Iranians differ from the others by being more evenly dispersed throughout the country on the province level. Like variations in degree of concentration between different immigrant groups, this suggests that the possibilities the different groups had when settling in Sweden have varied. Urbanization in general has affected residential patterns. Thus the possibilities have not been the same for the different immigrant groups because of variations over time in their competence and in their economic-geographical and sociodemographic preconditions. Furthermore, as regards Nordic immigration, geographical distance from the country of emigration is important for residential location. This distance, however, should be seen as an indicator of the geographical pattern's relevance to contact and information channels.

\section{Changes in size of population and degree of concentration}

Most of the immigrants were dispersed on the municipal level during the period studied (Table 1). However, between 1978 and 1984 most groups were concentrated. This is most likely due to the general economic recession in this period. Dispersion is more dramatic for those groups - for example, Chileans, Iranians and Norwegians whose populations increased. Finns comprise the only immigrant group who, like the Swedish population, has increased its degree of concentration throughout the entire 
period. This concentration occurred at the same time as a relatively strong population decrease among Finns in Sweden. Although it is often claimed that Finns are tantamount to 'brothers' and 'sisters' of Swedes, they socialize and have contacts primarily with their own countrymen (Borgegård 1974). A larger group means therefore more contact opportunities within the group, and thus more possibilities for dispersion.

The Hoover Index so far, based as it is on the local or municipal level, can conceal intraregional redistribution. The same Index, but on a provincial level, shows that this is actually not the case: redistribution as well as concentration and dispersion are interregional phenomena (Table 2). All immigrant groups except for Germans, are dispersed regionally. As on the local level, Finns, Norwegians, Danes, Germans, and Yugoslavs, i.e. the largest immigrant groups and those who have been in Sweden the longest, demonstrate the least change on the regional level. Finns are thus dispersed on a regional level while they are concentrated on the local level. This could indicate that immigrants, when the population decreases, get concentrated in, for example, regional centers as if they had acquired regional ties.

$\mathrm{T} a \mathrm{~b}$ le 2. Hoover Index of counties.

$\begin{array}{llllllllll} & \text { Swedish } & \text { Finnish } & \text { Norw. } & \text { Danish } & \text { German } & \text { Yugosl. } & \text { Chilean } & \text { Iranian } & \text { Turkish } \\ 1973 & 48.45 & 63.31 & 59.22 & 67.30 & 63.56 & 71.72 & . & . & 80.97 \\ 1978 & 48.47 & 62.68 & 59.03 & 65.63 & 63.50 & 72.33 & 78.69 & 71.89 & 77.72 \\ 1984 & 48.77 & 62.95 & 63.04 & 68.52 & 63.81 & 73.15 & 83.73 & 82.54 & 81.07 \\ 1988 & 49.20 & 62.89 & 60.40 & 65.34 & 64.21 & 72.34 & 74.43 & 54.68 & 78.45 \\ 1992 & 49.47 & 62.31 & 57.84 & 65.42 & 64.18 & 70.48 & 69.33 & 60.59 & 74.51\end{array}$

\section{Changes in the degree of concentration in light of prevailing policy}

One important factor influencing the residential patterns of the immigrants is government immigration policy. A conscious policy of dispersing immigrants will doubtless lead to immigrant populations being more dispersed than if the residential pattern was not regulated. This is because the process of adaptation for immigrants begins immediately when they have found somewhere to live in the country. In Sweden, there is also a relatively well-developed educational program for immigrants on the Swedish language and society. The Iranians' comparatively low degree of concentration is interesting in this connection, and may be deemed an indication that the "whole of Sweden' strategy has had a dispersing effect on residential patterns and that the concentration in large cities has diminished. On the local level, however, the Hoover Index shows (Table 1) that several immigrant groups live more dispersed than the Iranians. These groups, on the other hand, are composed of immigrants from Sweden's neighbors. Even so, the Iranians are more dispersed than an equally large immigrant population like the Yugoslavs. On the provincial level (Table 2), Iranians and Norwegians are the most dispersed. This means that the Finnish, Danish and German immigrants are regionally more concentrated, but in the provinces where they reside, they have a greater tendency to disperse.

It is clear that policy has had an impact on residential patterns. The degree of concentration, on both the local and provincial level, rose among the Iranians and Chileans up to 1984. After this concentration among both groups lessened on both geographical levels. The Index dropped on the municipal level by about 12 percentage points for Chileans, between 1984 and 1988, and for Iranians by 17 percentage points. This effect is also greater than the 'natural' population dispersion which occurs among most of the other immigrant groups. 


\section{Concluding discussion}

Underlying the subject of this article there are three different processes which affect the population distribution of foreign citizens in Sweden: first, the magnitude of international migration, second, the reasons people migrate to Sweden, and third, the integration of immigrants which affects domestic migration and thus the redistribution of the immigrant population in Sweden.

The increasing international migration since the 1950 s has increasingly effected population growth and population distribution in Sweden. The immigrants are more concentrated in the metropolitan areas than the Swedish population.

The "reasons" behind labor, family-related and refugee immigration, in combination with the geographical variations provided by structural conditions in society, determine where immigrants live. The geographical distribution of immigrant groups has different patterns. The labor immigrants primarily reside in the "old" industrial areas, while refugees are more unambiguously concentrated in the large cities. Family-related immigrants are basically related to the other two groups, so the residential patterns correspond. Immigrants from Sweden's Nordic neighbors primarily reside near the country of emigration.

The population redistribution of recent decades in terms of concentration and dispersion is summarized in Table 3. Changes have occurred in the 1960s-1970s with concentrations in industrial locations and with a certain dispersion/integration into these locations, while the 1980 s-1990s have involved a greater dispersion nationally and greater concentration locally. One important change since 1970 is that immigration has become regulated. Sweden has gone from no expressed immigration policy to a more regulated one. The composition of the immigrant population has changed and its residential pattern in Sweden has also been affected.

$\mathrm{T}$ a b l e 3. Changes in population of immigrants on different geographical levels.

$\begin{array}{llll} & \text { Residential } & \text { Local } & \text { Regional } \\ \text { Dispersion } & 1960 / 70 & 1980 / 90 & 1980 / 90 \\ \text { Concentration } & 1980 / 90 & 1960 / 70 & 1960 / 70\end{array}$

What is reflected in these patterns is that an increase of an immigrant group is accompanied by a parallel dispersion on a local and regional level. When an immigrant population diminishes, on the other hand, the concentration that occurs is much more sluggish - if it happens at all. There is a certain time interval between these events. The discrepancy could be explained by a greater integration which has led to new preferences and contact networks, which should halt concentration. Nevertheless, certain tendencies towards concentration on a local level may be detected amongst Finnish immigrants.

All immigrant groups in our study have acquired a more dispersed residential pattern on a regional and local level as they have increased in size and as they have prolonged their residency in Sweden. This occurs without any direct political intervention.

However, it is clear that the attempts to influence the residential patterns of immigrants have succeeded in affecting the geographical distribution. The groups to whom this applies have dispersed much more quickly than other immigrant groups. The question is whether the policy has not been too effective. At the end of the 1980 s, the Iranians' residential pattern, for example, became slightly more concentrated. This could 
perhaps have been prevented if the initial dispersion had been more moderate. However, this concentration is not in parity with the previous dispersion. The increase in the Hoover Index today, could be seen more as an effect of current regional potentials - something that virtually does not exist for Yugoslavs and Turks, for instance. Although concentration is intensifying among the Iranians, the residential patterns will probably stay more dispersed due to the fact that the integration process is beginning and new contact possibilities are being created. This more dispersed residential pattern is thus a result of policy (see also Andersson 1993).

In the present study it has been fruitful to divide the immigrant population into different nationalities to show what is similar and what differs between the population distribution of the immigrant groups in the country over time. This has enabled us to see how different restrictions on immigration on an aggregate level affect residential patterns. Normally immigrants are dealt with as one group. Our study has shown that different immigrant groups have different residential patterns in Sweden, but also similar patterns when it comes to population redistribution in terms of concentration and dispersion. How rapid and extensive a dispersion becomes varies according to nationalities, which means that their backgrounds are important for the process. Further, this dispersion can in part be determined and accelerated through political measures. It is therefore important to continue research on changes in the geographical residential patterns of immigrants in order to expand knowledge and understanding of the processes affecting immigrants in the country in which they have arrived. In a society which is increasingly multi-cultural, such knowledge can also contribute to a greater understanding of the geographical distribution of the population.

\section{References}

Andersson, Roger. 1993. Immigration policy, and the geography of ethnic integration in Sweden. Nordisk Samhällsgeografisk Tidskrift 16:3-29.

Berry, Bryan J. L. 1993. Transnational urbanward migration, 1830-1980. Annals of the Association of American Geographers 83:389-405.

Borgegård, Lars-Erik. 1974. Finländares och svenskars levnadsvilkor: En fallstudie frîn Virsbo samhälle i Västmanlands län (The living conditions of the Finns and Swedes: a case study of Virsbo community in the province of Västmanland. Working paper. Umeå: Umeå University: Department of Geography.

Borgegîrd, Lars-Erik, Johan Håkansson and Gunnar Malmberg. 1995. Population redistribution in Sweden: a brief historical background to contemporary trends. Geografiska Annaler 77B:31-45.

Borgegård, Lars-Erik and Johan Håkansson. 1995. Spridning och koncentration i Sveriges kommuner 1973-1992 (Dispersion and concentration in Swedish municipalities 1973-1992). In: Då, Nu och Sedan: Geografiska Uppsatser till Minnet av Ingvar Jonsson, edited by Ian G Layton, Gerum nr 27, Umeå: Umeå University, Department of Geography.

Castles, Stephen. and Mark J. Miller. 1993. The Age of Migration: International Population Movements in the Modern World. New York: Guilford Press.

Champion, Anthony G. 1994. International migration and demographic change in the developed world. Urban Studies 31:653-77.

Collinson, Sarah. 1993. Europe and International Migration. London, UK: Pinter.

Duncan, Otis D., Ray B. Cuzzort and Beverly Duncan. 1961. Statistical Geography. Glencoe, IL.: The Free Press.

Fassmann, Heinz and Rainer Münz. 1994. Patterns and trends of international migration in western Europe. In: European Migration in the Late Twentieth Century: Historical Patterns, Actual trends, and Social Implications, edited by Heinz Fassmann and Rainer Münz, pp. 3-33. Laxenburg, Austria: IIASA.

Gould, William T.S. 1988. Skilled international labour migration: an introduction. Geoforum 19: $381-5$.

Hammar, Tomas. 1992. Laws and policies regulating population movements: a European perspective. In: International Migration Systems: A Global Approach, edited by Mary M. Kritz, Lin L. Lim and Hania Zlotnink, pp. 1-16. Oxford, UK: Clarendon Press. 
Hoover, Edgar M. 1941. Interstate redistribution of population, 1850-1940. Journal of Economic History 1:199-205.

Håkansson, Johan. 1992. Invandrare i Sverige: Deras geografiska fördelning och flyttningsrörelser (Immigrants in Sweden: geographical distribution and mobility). BA thesis. Umeå: Umeå University, Department of Geography.

Häggström, Nils, Lars-Erik Borgegård and Annette Rosengren. 1990. När Finländarna Kom: Migrationen Finland-Sverige Efter Andra Världskriget (When the Finns came: Migration from Finland to Sweden after World War II). Gävle: SIB.

Isard, Walter. 1960. Methods of Regional Analysis: An Introduction to Regional Science. Cambridge, MA: M.I.T. Press.

King, Russel ed. 1993. Mass Migration in Europe: The Legacy and Future. London, UK: Belhaven,

Lundh, Christer and Rolf Ohlsson. 1994. Från arbetskraftsimport till flyktinginvandring (From labor to refugee migration). Stockholm: SNS.

Müller, Dieter K. 1994. West-European immigration to Sweden. Paper presented at the conference: Population Planning and Policies, September 1994, Laxön:. Umeå: Umeå University, Department of Geography.

Salt, John. 1993. External international migration, In: The Changing Population of Europe, edited by Daniel Noin and Robert Woods, pp. 185-97. Oxford: Blackwell.

Salt, John. ed. 1992. People on the Move: New Migration Flows in Europe. Strasbourg, France: Council of Europe.

White, Paul. E. 1993. The social geography of immigrants in European cities: the geography of arrival, In: The New Geography of European Migrations, edited by Russel King, pp. 47-66. London: Belhaven.

Widgren, Jonas. 1986. Svensk Invandrarpolitik (Swedish Immigration Policy). Lund: Sandby Grafiska.

Vining, Daniel R. Jr. and A. Strauss. 1977. A demonstration that the current deconcentration of population in the United States is a clean break with the past. Environment and Planning 9:751-8. 